S. I. Cheberiachko, Dr. Sc. (Tech.), Assoc. Prof., orcid.org/0000-0003-3281-7157, A. V. Yavorskyi, Cand. Sc. (Tech.), Assoc. Prof., orcid.org/0000-0003-4484-3723,

O. O. Yavorska, Cand. Sc. (Tech.), Assoc. Prof., orcid.org/0000-0001-5516-5310,

V.V.Tykhonenko,

orcid.org/0000-0001-6919-557X
National Mining University, Dnipro, Ukraine,e-mail: elenayavorska80@gmail.com

\title{
EVALUATING THE RISKS OF OCCUPATIONAL RESPIRATORY DISEASES OF COAL MINE WORKERS
}

Purpose. To determine the degree of occupational risks in terms of respiratory diseases (pneumoconioses) of miners while using dust respirators.

Methodology. The approach described in DSTU-P OHSAS 18001:2006 "Systems to control occupational safety and health. Requirements" has been used to assess occupational risks.

Findings. It has been determined that the area of safe use for filtering half-masks in the context of coal mines should be limited by 5 MAC. Calculation of the risk level while applying Risk score method has demonstrated that in terms of coal dust concentration being more than $20 \mathrm{mg} / \mathrm{m}^{3}$, dust respirators make it possible to provide only moderate degree of occupational disease risk. In this context, there is an excess in under-mask dust concentration in a respirator up to $18 \%$, in terms of $2 \mathrm{mg} / \mathrm{m}^{3} \mathrm{MAC}$. It is noted that if respirators are not worn or if they are taken off for more than five minutes during the operating shift in terms of constant dustiness, it results in the increase in undermask dust concentration by almost three times.

Originality. Originality is in scientific substantiation of the safe dust concentration, when it is possible to provide minimum pneumonoconiosis risk while using a filtering respirator.

Practical value. Certain measures to reduce the level of pneumonoconiosis risk have been proposed. Increase in the protection efficiency for miners is possible owing to the intensification of the control of individual dust load which will be evaluated taking into consideration real time of respirator use and changes in dust concentration within the working zone. It is recommended to use of electronic monitoring means developed on the basis of pressure sensors, power units, control units, information process units, alarm blocks, and block for data record and storage.

Keywords: coal mine, dust, pneumonoconiosis, risk value, specific dedusting, coal shearer, dedusting means

Introduction. Pneumonoconiosis is a serious lung disease being the result of inhaling finely dispersed dust particles. It is most often recorded in case of workers of coal industry which involves production processes dealing with coal extraction, transportation, and processing [1]. It is no doubt that there are rather drastic consequences when coal dust enters the worker's lungs. The assumption is proved by numerous studies as for the risks of lung troubles caused by harmful aerosol penetration [1]. For instance, paper [2] indicates that in the USA, within the period of 1970-2004, 69277 miners died due to pneumonoconiosis. Such a situation has forced Mine Safety and Health Administration, MSHA (the USA) to develop a set of requirements for employers stipulating the decrease in coal dust concentration in mine workings down to $2 \mathrm{mg} / \mathrm{m}^{3}$. Nevertheless, the period of 2000-2006 demonstrated the growth of diseases due to dust factor in case of miners with more than 20 years of work experience; that is a significant problem requiring implementation of new and more sever approaches to solve the problem [2].

Basing upon the analysis of published open information sources (Krutenko, S. O., et al. Dust conditions and

(c) Cheberiachko S.I., Yavorskyi A.V., Yavorska O.O., Tykhonenko V.V., 2018 pneumonoconiosis in terms of mines of Ukraine), Ukrainian mine workings are characterized by so-called residual dustiness levels being ten times higher than the maximum admissible ones. The latter are a bit higher than in the USA; they depend upon the content of silicon dioxide. Such a situation requires implementation of the system of risk control in reliance on ISO 45000, basing upon the individual control of a miner's dust load, and calculation of safe operating time under dusty conditions, according to the convention and instructions as for determining admissible time for the workers operating under harmful conditions, proved by the Order of the Ministry of Health of Ukraine No. 820 of 12.12.2006. Moreover, legislation on labour safety stipulates the provision of workers with the means of individual protection to operate under hazardous conditions, according to the Regulations on the workers' provision with special clothing, special footwear, and other means of individual protection approved by the Order of State Committee of Ukraine for Labour Safety Control, No. 170 of 29.10.1996 Means of Individual Protection.

Basing upon the aforementioned, we consider that the studies aimed at reducing the risk of dust-etiology occupational diseases are rather topical.

Statement of the problem. European legislation, in particular, Directive of the EU, p. 89/391. EW9, and 
Standard ISO 45000 stipulate the priority of the use of collective protective devices over the individual ones. However, employers use the first ones according to their awareness and financial possibilities which cannot always reduce the occupational disease level down to the required index. In such a case, individual respiratory protective devices (IRPD) should be used. Besides, according to the requirements of the Hygienic Classification of Labour approved by the Order of the Ministry of Health of Ukraine (of 08.04.2014, No. 248), while using efficient individual protection devices, it is possible to reduce the level of occupational health risks and assess the working conditions as less harmful ones (according to the Certificate of IPD compliance) but not lower than degree 3.1 of class 3 . Taking into account the fact that the implementation of the latter is much cheaper comparing to the collective protective devices, their wide use is obvious. There arises a topical problem: how much the use of effective IPD may reduce the occupational disease risks.

Analysis of the recent research and publications. Analyzing the experience of assessing occupational disease risks for miners, scientists point out high probability of occupational dust-etiology respiratory diseases. First of all, such a situation is stipulated by low efficiency of technical means of collective protection: ventilation of local suction devices built in a shearer; air showers which do not allow reducing dustiness within the breathing zones down to the admissible values due to complicated mining and geological operating conditions and physical and chemical properties of minerals. Thus, at that stage, risks are tried to be reduced by the use of respirators. However, there are two contradicting ideas. One of them states that IPD use reduces the risks; for instance, paper [2] by Levishko K. V. tells that the respirator helps reduce silicosis cases down to the safe value basing upon the probability calculation of occupational diseases of miners. Similar conclusions may be found in specialized literature and regulatory documents concerning labour safety as well, e.g. in SRALS 0.00-1.04-07 Rules to select and use individual respiratory protective devices.

Another one indicates that the protective level of respirators is low; thus, they should be used as an additional protective device. The idea is based on numerous results of studies under working conditions:

- various factors effect protective efficiency of filtering respirators, and the factors reduce considerably the efficiency specified by the manufacturers; key factors include operating conditions, operating rate and rhythm, climatic parameters, concentration of harmful substances etc. [3, 4];

- in terms of proper selection of a filter and respirator in general, its efficiency is determined by the penetration of unfiltered air through the gaps between facial part of a half-mask (respirator) and a face which is considered to be the main way of the inhaled air contamination [4]; modern filters are characterized by low penetration coefficient (up to $0.01 \%$ ) while in terms of half-masks, suction coefficient should be not more than $2 \%$ (under laboratory conditions);

- availability of gaps between a half-mask and a face depends upon great amount of factors (face anthropometry, obturator design, headpiece, resistance of filters, head movements, breathing mode, etc.); they are unsteady being of different shape and dimensions resulting in the fact that a coefficient of protection may change by ten times just within several minutes - that is an inconstant, random, and unpredictable value [5];

- under working conditions, leakage may me more intense than under laboratory ones (e.g. during certification), there is no clear connection between them [6].

Thus, direct use of the laboratory results, contrary to the generally accepted approach [7] to assess the respirator efficiency as for the disease risks while its using, is inadmissible. That means that manufacturers should evaluate real efficiency of a respirator being determined either under production conditions or being calculated basing upon the operating conditions.

It should be also noted that there are almost no calculations dealing with the evaluation of occupational disease risks taking into account respirators; the available rare publications do not consider the probability of protective properties deterioration due to a human factor.

Objective of the paper is to determine the risk of occupational diseases of respiratory organs (silicosis) of miners while using filtering respirators.

Methods of the research. To determine the risk according to ISO/IEC 31010:2009, we use rather welltested method Risk score which takes into consideration basic requirements of classic British standard BS- 8800 [8]. The essence is in the determination of the potential dangers, evaluation of severity of consequences (Table 1), probability of each danger in different variants (Table 2), and its frequency of occurrence (Table 3). Risk value $(R)$ is determined in points from 1 to 30 (Table 4) according to formula [8]

$$
R=S \cdot E \cdot P,
$$

where $S$ is severity of consequences; $E$ is frequency of occurrence; $P$ is probability of occurrence.

Findings. To evaluate the risks of occupational diseases of miners' lungs, it is required to come up with three components: severity of consequences, probability of occurrence, and frequency of occurrence.

In terms of the first one, we adopt the highest level of hazard. Numerous studies concerning the health of mining industry workers after their contact with dust aerosol carried out by national specialists of the Institute of Occupational Medicine of the National Academy of Medical Sciences (Mukhin, V.V., Kundiiev, Yu. I., Basanets, A. V., Lubiianova, I. P.) [10] have shown that coal (especially, quarts) dust inhaling results not only in lung damage but also in depression of functions of central and vegetative nervous systems, damages in cardiovascular, lymphatic, and digestive systems (development of hypoacid gastritis), etc.

To determine the value of occurrence probability, it is required to specify the fact to what extent dustiness level in coal mines and dust concentration within the under-mask area entering the worker's lungs protected by a respirator may exceed MAC. 
Criteria to determine severity of consequences

\begin{tabular}{|l|l|}
\hline $\begin{array}{l}\text { Mild (inconveniences, irritations, mild disease) } \\
\text { Level } 1\end{array}$ & $\begin{array}{l}\text { The occurrence results in a short-period disease or health deterioration } \\
\text { which do not require medical attention. } \\
\text { Absence from work is possible up to three days. For instance, headache, dry } \\
\text { cough, increased fatigue }\end{array}$ \\
\hline $\begin{array}{l}\text { Moderately severe (persistent subatrophic, } \\
\text { atrophic changes) }\end{array}$ & $\begin{array}{l}\text { The occurrence results in considerable and long-term consequences. It } \\
\text { requires medical attention. For instance: severe worsening fibrosis with } \\
\text { respiratory depression, evident obstructive pulmonary emphysema. There is } \\
\text { a pain syndrome in a chest while moving }\end{array}$ \\
\hline $\begin{array}{l}\text { Severe (occupational cancer, asthma) } \\
\text { Level 3 }\end{array}$ & $\begin{array}{l}\text { The occurrence results in constant and irreversible damages. It requires hospital } \\
\text { treatment; absence from work is more than 30 days. For instance: profuse } \\
\text { miliary infiltration, constant dry cough, evident bronchial emphysema, } \\
\text { available asthmatic component, possible cancer of bronchi or lungs }\end{array}$ \\
\hline
\end{tabular}

Table 2

Criteria to determine probability of the occurrence

\begin{tabular}{|l|l|}
\hline $\begin{array}{l}\text { Low probability } 1 \\
\text { Level } 1\end{array}$ & $\begin{array}{l}\text { A miner is in the dusty zone for a short } \\
\text { period of time. Dust content in a mine } \\
\text { atmosphere is low being within the } \\
\text { admissible limits }\end{array}$ \\
\hline $\begin{array}{l}\text { Probable } \\
\text { Level } 2\end{array}$ & $\begin{array}{l}\text { A miner is in the dusty zone for a long } \\
\text { period of time. Dust content in a mine } \\
\text { atmosphere is high - MAC* is higher by } \\
\text { up to 4 times }\end{array}$ \\
\hline $\begin{array}{l}\text { Hevel } 3 \\
\text { High probability }\end{array}$ & $\begin{array}{l}\text { A miner is in the dusty zone constantly. } \\
\text { Dust content in a mine atmosphere is } \\
\text { inadmissible - MAC* is higher by more } \\
\text { than 4 times }\end{array}$ \\
\hline
\end{tabular}

*-maximum admissible concentration

Table 3

Ranging of the occupational disease frequency

\begin{tabular}{|c|l|}
\hline Value E & \multicolumn{1}{|c|}{ Characteristics } \\
\hline 4 & $\begin{array}{l}\text { Constant staying within the dusty zone, } 100 \% \text { of } \\
\text { operating time }\end{array}$ \\
\hline 3 & $\begin{array}{l}\text { Everyday staying within the dusty zone but not } \\
\text { more than } 50 \% \text { of operating time }\end{array}$ \\
\hline 2 & Periodical staying within the dusty zone \\
\hline 1 & Accidental staying within the dusty zone \\
\hline
\end{tabular}

Table 4

Rank scale of risk value due to the dust effect taking into account frequency of staying within the dusty zone

\begin{tabular}{|l|c|}
\hline \multicolumn{1}{|c|}{ Risk } & Points \\
\hline Inadmissible & $28-36$ \\
\hline Considerable & $24-27$ \\
\hline Moderate & $16-24$ \\
\hline Low & $8-16$ \\
\hline Minor & $1-8$ \\
\hline
\end{tabular}

Basing upon the published data, we can see that dust concentration in coal mines of the USA is within the range of $1-8 \mathrm{mg} / \mathrm{m}^{3}$. In this context, the greatest dust share is generated near coal shearers. In terms of Russian and Ukrainian coal mines, nothing but dust levels (after the application of dedusting and ventilation systems) may reach up to $100 \mathrm{mg} / \mathrm{m}^{3}$.

Decrease in the solid aerosols concentration $C_{i}$ owing to the use of filtering respirators may be evaluated according to the formula proposed by Warren, R. M.

$$
C_{i}=\frac{\left(Q-Q_{c}\right) K_{p}^{f} C_{0}+Q_{c} K_{p}^{g} C_{0}}{Q}
$$

where $Q$ is general air consumption through a respirator, $\mathrm{m}^{3} / \mathrm{s} ; Q_{c}$ is air consumption through the gaps in the obturation line, $\mathrm{m}^{3} / \mathrm{s} ; K_{p}^{f}$ is coefficient of penetration through a filtering elements; $K_{p}^{g}$ is coefficient of penetration through the gaps due to leakage points in an obturator or exhalation valve; and $C_{0}$ is concentration of harmful substance in the air of the working zone, $\mathrm{mg} / \mathrm{m}^{3}$.

Penetration coefficient of filters is a known value. For instance, in terms of the most popular brands of second-protection class filters P95 (P2 according to European classification), it is within the range of $K_{p}^{f}=0.01 \ldots 0.1$. Even when different harmful factors (exposure to radioactive aerosols or isopropanol treatment), capable of deteriorating their efficiency, effect modern filters, their efficiency is not beyond the limits determined by the standards. Pay attention to the fact that dusting processes improve filters' catching of aerosol particles since pores between fibers decrease and additional self-purifying dust layer is developed on its surface.

Coefficient of penetration through leakage points of an obturator or exhalation valves is much more difficult to be evaluated. The most common formula to do that is proposed by Hinds

$$
\begin{gathered}
K_{p}^{g}=1-5.5 k_{2}^{\frac{2}{3}}+3.77 k_{2} \quad \text { if } \quad k_{2}<0.009 \\
K_{p}^{g}=0.819 \exp \left(-11.5 k_{2}\right)+0.0975 \exp \left(-70.1 k_{2}\right) \\
\text { if } k_{2}>0.009,
\end{gathered}
$$

where $k_{2}=\frac{D L_{1}}{Q_{c}} ; L_{1}$ is length of a gap or a tube, $\mathrm{m} ; D$ is coefficient of suction. 
However, to use the formula, we need certain data on the size of gaps and value of air consumption through them. The process is effected by numerous factors, i.e. the obturator area, material it is made of, complexity of operations, anthropometric characteristics of workers' faces etc. It has been determined experimentally that the size of gaps may be within the range of $0.7 \mathrm{~mm}$ up to $3.5 \mathrm{~mm}$ [9]. In this context, the majority of specialists recommend determining air consumption through the gaps between a face and a half-mask according to the formula proposed by Han, D.H.

$$
Q_{c}=k_{c}(\Delta p)^{a}\left(d_{g}\right)^{b},
$$

where $Q_{c}$ is air consumption through the leakage points along the obturation line, $1 / \mathrm{min} ; k_{c}, a, b$ are constants being determined experimentally for each half-mask type; $d_{g}$ is size of gaps between an obturator and a human face; and $\Delta p$ is pressure difference on a respirator, $P_{a}$ (constants $k_{c}, a, b$ for elastomeric half-masks may be taken in some approximation as $0.05,0.65,0.5$ respectively).

One more parameter required to calculate suction values is represented by the change in pressure difference of a respirator while dusting. For instance, in terms of pleated filters of P95 class or corrugated ones of P2 class, increase in the airflow resistance while dusting, according to the papers by Plebani, S. Listrani and M. Di. Luigi, is represented in Table 5.

Table 6 represents values of suction through possible gaps along the obturation ling of a half-mask being calculated according to (5).

Basing upon the obtained suction values according to (2), it has been determined that if the size of an equivalent gap along the obturation line is more than $2.5 \mathrm{mcm}$, then there is practically no efficiency of respirator protection. Thus, there arises the necessity in previous testing of half-mask compliance with the anthropometric features of a face involving both qualitative and quantitative testing methods. Qualitative method is based upon the subjective reaction of sense organs to a strong smell of the dispersed safe aerosols: saccharine, Bitrex, isomethyl acetate, etc. Quantitative methods are based upon the instrumental testing. They are better than the aforementioned ones as they use special equipment, which records the available leakage of the aerosol into the half-mask area. Determination of suction coefficient according to EN 529 fit test is the most widespread one. Its essence is in the specification of the ratio of external test-aerosol concentration to the under-mask one. Another simple method to assess protective properties of respirators is a quit test. Its essence is in the determination of air suction value in terms of the developed rarefaction under a half-mask with the help of a small pump and a pressure sensor. A testee, with a put-on respirator which filters are tightly closed with special caps, holds his/her breath for several seconds; when breath is being held, the pump connected through a valve system is switched on to pump out little air. During the process, rarefaction is being developed which is recorded by a pressure sensor. The rarefaction will decrease due to pressure difference and air leaking into the under-mask
Table 5

Results of studying changes in pressure difference on filters to a respirator while dusting

\begin{tabular}{|c|c|c|c|c|c|}
\hline \multirow[t]{2}{*}{$\begin{array}{c}\text { Type of a filter to } \\
\text { a respirator }\end{array}$} & \multirow[t]{2}{*}{ 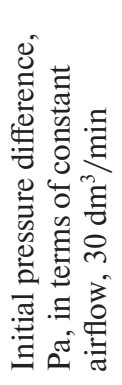 } & \multicolumn{4}{|c|}{ 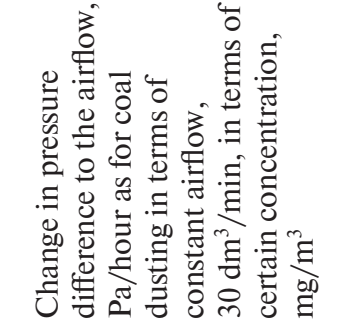 } \\
\hline & & 15 & 20 & 50 & 100 \\
\hline P95 (pleated) & 21 & 0.8 & 2.5 & 5.9 & 15.7 \\
\hline P2 (corrugated) & 19 & 0.6 & 1.2 & 3.9 & 8.7 \\
\hline
\end{tabular}

Table 6

Air consumption through the tubes mounted along the obturation line

\begin{tabular}{|c|c|c|c|}
\hline \multirow[b]{2}{*}{$\begin{array}{c}\text { Equivalent } \\
\text { gap diameter, } \\
\mathrm{mm}\end{array}$} & \multirow[b]{2}{*}{$\begin{array}{c}\text { Pressure } \\
\text { difference on } \\
\text { a respirator, } \\
\mathrm{Pa}\end{array}$} & \multicolumn{2}{|c|}{ Air consumption, $1 / \mathrm{min}$} \\
\hline & & $\begin{array}{c}\text { General } \\
\text { through } \\
\text { a respirator }\end{array}$ & $\begin{array}{l}\text { Leakage } \\
\text { through gaps } \\
\text { (according to } \\
\text { the formula) }\end{array}$ \\
\hline 1 & \multirow[t]{4}{*}{20} & \multirow[t]{4}{*}{3000} & 390 \\
\hline 2 & & & 545 \\
\hline 2.5 & & & 609 \\
\hline 5 & & & 862 \\
\hline
\end{tabular}

area. However, pressure sensor reacts to the change; the sensor switches on the pump again to pump out air until there is the initial rarefaction value. The amount of air being pumped out corresponds to the one penetrated through leakage points. The whole procedure takes only 7-10 seconds.

Basing upon the abovementioned, assess the value of suction through the gaps along the obturation line of a standard elastomeric half-mask for the worst case (value of possible equivalent (total) gap along the obturation line is up to $20 \mathrm{~mm}$ ) during a six-hour working shift. Moreover, calculate the mass of the dust entered the miner's lungs after respirator use according to the known formula

$$
D=C_{i} Q t,
$$

where $D$ is mass of the dust to enter the lungs, $\mathrm{mg} ; C_{i}$ is dust concentration after respirator use, $\mathrm{mg} / \mathrm{m}^{3}$ (calculated according to formula 1 taking into account formulas 3,4); $Q$ is air consumption, $\mathrm{m}^{3} / \mathrm{min}$; and $t$ is time of the working shift, $\min$.

Value of changes in pressure difference of filters during dust deposit accumulation in terms of dust concentrations being less than the ones represented in Table 5 was reduced proportionally to the dust concentration. For instance, in terms of dusting with $15 \mathrm{mg} / \mathrm{m}^{3}$ concentration, pressure difference is $0.8 \mathrm{~Pa}$ /hour, while in terms of $10 \mathrm{mg} / \mathrm{m}^{3}$ dust concentration, the increase is 
reduced down to $0.53 \mathrm{~Pa}$ /hour. Table 7 demonstrates the calculations.

The latter index - frequency of disease occurrence will be considered as the greatest one since miners contact the dust for almost all their working time.

Thus, taking into consideration the fact that there are severe consequences of dust coal inhaling for workers' health and disease possibility is within the range of 1-3 points depending upon the mass of the accumulated aerosol, it is possible to determine risk level of occupational disease. Table 8 contains the calculation results.

Discussion of the research results. The obtained results show that dust respirators decrease the level of disease risks; however, they do not eliminate those risks completely. It is clearly seen that in terms of dust concentration being up to $20 \mathrm{mg} / \mathrm{m}^{3}$, dust respirators make it possible to provide only moderate risk level. Here, the excess in under-mask dust concentration in a respirator up to $18 \%$ is recorded. It is understood that its exceedance results in practically no protection for workers against a disease even if they wear respirators. It should be noted that in most European countries value of safe dust concentration when it is allowed to use IRPD with elastomeric half-masks is specified at the level of 20

Table 7

Results of calculating under-mask dust concentration

\begin{tabular}{|c|c|c|c|c|c|c|}
\hline 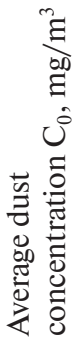 & 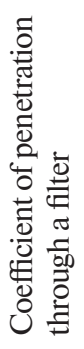 & 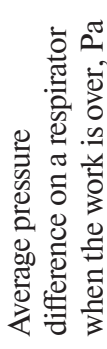 & 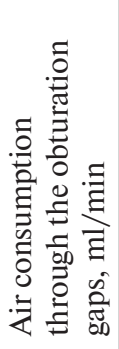 & 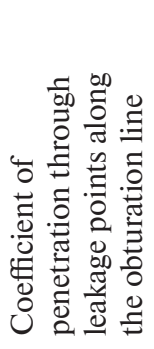 & 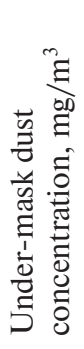 & 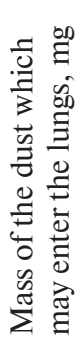 \\
\hline 1 & \multirow[t]{5}{*}{0.1} & 21.4 & 390 & 0.31 & 0.12 & 0.13 \\
\hline 2 & & 21.7 & 400 & 0.33 & 0.26 & 0.28 \\
\hline 5 & & 22.6 & 410 & 0.34 & 0.66 & 0.71 \\
\hline 10 & & 24.2 & 430 & 0.36 & 1.3 & 1.47 \\
\hline 20 & & 27.4 & 450 & 0.38 & 2.8 & 3.07 \\
\hline
\end{tabular}

Table 8

Results of calculating a reference level of pneumoconiosis occurrence risks

\begin{tabular}{|c|c|c|c|c|}
\hline 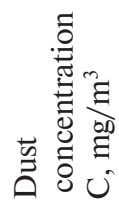 & 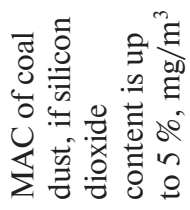 & 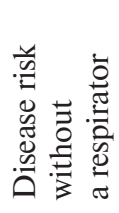 & 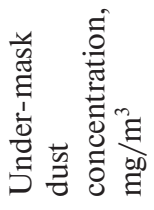 & 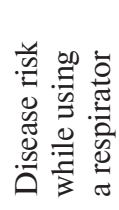 \\
\hline 1 & \multirow{5}{*}{2} & 12 & 0.12 & 12 \\
\hline 2 & & 12 & 0.26 & 12 \\
\hline 5 & & 24 & 0.66 & 12 \\
\hline 10 & & 36 & 1.3 & 12 \\
\hline 20 & & 36 & 2.8 & 24 \\
\hline
\end{tabular}

MAC being twice higher than the abovementioned values.

Working within the zones with up to $10 \mathrm{mg} / \mathrm{m}^{3}$ dust concentration is also dangerous for miners even irrespective of the fact that the risk level is "low". In due course, when considerable dust mass is accumulated in lungs, various morphological changes may develop in this organ with their further transformation into chronic pneumoconiosis. That is proved by clinical studies by Miller, B. G., Hagen, S, Love. R.G., Soutar, C.A., Cowie, H.A., Kidd, M.W. and Robertson, A. (Risks of silicosis in coalworkers exposed to unusual concentrations of respirable quartz); the researchers point out that in 15year period up to $5 \%$ of miners will fall sick with silicosis, if they inhale $0.1 \mathrm{mg} / \mathrm{m}^{3}$ of quartz, and up to $2 \%$ miners will fall sick, if they inhale $0.05 \mathrm{mg} / \mathrm{m}^{3}$ of quartz. In addition, one should not neglect a human factor: workers may put off their half-masks while operating. Besides, respirators may slide while performing various operations resulting in the increased amount of the exhaled dust. For instance, if workers did not use respirators for only 5 minutes during their 480-minute shift ( 8 hours), then, in terms of constant air contamination being $10 \mathrm{MAC}$, it is impossible to provide decrease in harmful substance concentration within the undermask area down to the safe level under conditions of any respirator efficiency within following 475 minutes. Thus, the amount of dust entering the lungs (determined according to formula 6) while using respirator is $2.8 \mathrm{mg}$ during 475 minutes while 5 minutes without a respirator demonstrate the value of $3.9 \mathrm{mg}$. Generally, that is higher than MAC. Consequently, improper use of a respirator when there is no obvious life and health hazard as well as taking it off because of some reasons is one of the most serious unsolved problems of respiratory protection use.

Recommendations of different European countries as for the selection of individual respiratory protection devices place an emphasizes on a set of factors which may deteriorate considerably protection of workers. In this context, most problems arise when it is required to provide reliable isolation of respiratory organs by means of half-masks due to the anthropomorphic differences of faces. Attention should be also paid to such problems as the nonavailability of speech diaphragms and complexity in determining protection period. That requires the employers to implement a system of rigid control of proper IRPD use being always a problem. The Figure demonstrates a fragment of working table HAZOP to determine risks of reducing protective properties of respirators basing upon one parameter only - coefficient of protection. The analysis demonstrates that there are at least five influential factors which may reduce the efficiency of a certain parameter. That needs further development, implementation, and performance of the respiratory protection programme requiring corresponding economic expenditures and trained specialists; nevertheless, no measures guarantee complete reduction of the indicated risks.

According to the calculations by Mark Nikas, famous researcher and specialist dealing with the evalua- 
tion of safe area of respirator use, it has been determined that there will always be a group of workers with insufficient IRPD coefficient of protection due to the instability of that very coefficient. Thus, while using good-quality IRPD, it is not allowed to reduce the level of occupational health risk and evaluate working conditions as less hazardous, as it is stated in the Hygienic Classification.

Nowadays, increase in protective efficiency with the help of IRPD is possible owing to the intensification of their efficient use control, e.g. half-masks may contain special electronic systems making it possible to control the working time spent while wearing them, changes in pressure difference, and coefficient of dust penetration. There is a well-known method of fast testing of protective properties of respirators in terms of pressure difference changes. It is based upon the reduction of the initial airflow resistance on a respirator due to suction along the obturation line comparing to the tightly fixed one. It is proposed to control changes in breathing resistance using special meter consisting of pressure sensor, powersupply units, units to control and process information, signal blocks, and units to record and store data. Pressure sensor is located within the under-mask area of a respirator (it may be fixed in a gap for exhalation valve). Output information is transmitted from the sensor to the control unit where it is compared with the specified one (minimal pressure difference in terms of leak-proof half-mask arrangement, being determined at the stage of its selection); then, control signals to switch on light and sound indicators are produced. If value of breathing resistance is lower than the specified one, sound or light signal is produced meaning that there is suction along the obturation line of a respirator due to its sliding, stretching of headpiece bands or some other reasons. The signal requires either problem elimination or IRPD replacement.
However, analysis of the occupational disease risks demonstrates that working conditions and time of miner's contact with dusty medium have the greatest effect upon their values. It means that changes in coal mining technology favouring the removal of workers from the hazardous zones are the best protective measures.

The considered problems of the occupational disease development are reflected in labour safety standards regulating IRPD use. Employers in the USA, Germany, and Great Britain are obliged to carry out biomonitoring while examining their workers. Concentrations of some harmful substances in biological environment (blood and others) and changes in metabolic processes make it possible to analyze the protection level. Nowadays, various biomonitoring methods have been developed and used to assess the effect of about 80 harmful substances; the methods make it possible to determine considerable influence of those substances (Biological Exposure Indexes BEI, biological MAC). Biomonitoring is the auxiliary way making it possible to evaluate general efficiency of all the measures taken to protect against the harmful substance effect (including IRPD use).

To reduce the occupational disease risks for workers using IRPD, it is required:

1) to reduce the area of safe use of filtering halfmasks in terms of coal mines down to $10 \mathrm{mg} / \mathrm{m}^{3}$, which will correspond to $5 \mathrm{MAC}$ level;

2) to increase the control of miner's individual dust load that will be evaluated taking into account real time of respirator use and changes in dust concentration within the working zone owing to the use of electronic means of control;

3 ) to revise the requirements for the selection of efficient IRPD for workers and corresponding training programs basing upon modern technological level.

\begin{tabular}{|c|c|c|c|c|c|c|c|}
\hline No. & $\begin{array}{c}\text { Control } \\
\text { word }\end{array}$ & Deviation & Reasons & Consequences & $\begin{array}{l}\text { Measures to eliminate } \\
\text { defects }\end{array}$ & Recommendations & Priority \\
\hline 1 & LESS & $\begin{array}{l}\text { Coefficient } \\
\text { of protection }\end{array}$ & $\begin{array}{l}\text { 1. Half-mask } \\
\text { incompliance } \\
\text { with a face. } \\
\text { 2. Poor filter. } \\
\text { 3. Use of a filter } \\
\text { for a period } \\
\text { longer than its } \\
\text { service life. } \\
\text { 4. Use of an } \\
\text { inadequate } \\
\text { filter type. } \\
\text { 5. Untimely } \\
\text { and wrong use } \\
\text { of a half-mask. } \\
\text { 6. Use of } \\
\text { damaged filter } \\
\text { half-masks }\end{array}$ & $\begin{array}{l}\text { Health deterioration, } \\
\text { decreased working } \\
\text { efficiency, } \\
\text { development of } \\
\text { respiratory } \\
\text { occupational diseases } \\
\text { due to ineffective } \\
\text { respiratory protection }\end{array}$ & $\begin{array}{l}\text { Implementing } \\
\text { instrumental methods } \\
\text { to test half-mask } \\
\text { compliance with a face. } \\
\text { Use of filters with the } \\
\text { certificate of } \\
\text { compliance, reliable } \\
\text { suppliers and } \\
\text { manufacturers with the } \\
\text { approved quality } \\
\text { system. } \\
\text { Determining service } \\
\text { life of filters taking into } \\
\text { account specific } \\
\text { working conditions. } \\
\text { Checking identification } \\
\text { marks of filters and } \\
\text { defining which aerosol } \\
\text { type they are used }\end{array}$ & $\begin{array}{l}\text { To implement a } \\
\text { program for respiratory } \\
\text { protection with the } \\
\text { elements of quality } \\
\text { control for respirators } \\
\text { being supplied, } \\
\text { operate, and stored. To } \\
\text { organize periodical } \\
\text { staff training as for the } \\
\text { proper use of } \\
\text { respirators }\end{array}$ & 1 \\
\hline
\end{tabular}

Fig. Fragment of working table HAZOP to determine risks of deterioration of the respirator protection coefficient 


\section{Conclusions.}

1. It has been determined that the area of safe use of filtering half-masks in terms of coal mines should be limited by 5 MAC as it is impossible to provide proper protection of workers' respiratory organs even if high-quality IRPD are applied. That is stipulated by a human factor being rather difficult to control. Thus, while using filtering respirators, it is not allowed to reduce the level of occupational disease risk and evaluate working conditions as less harmful, as it is stated in the Hygienic Classification.

2. Calculation of risk level while using Risk score method has shown that in terms of coal dust concentration being more than $20 \mathrm{mg} / \mathrm{m}^{3}$, the available dust respirators make it possible to provide only moderate level of occupational disease risk. In this context, increase in under-mask dust concentration in a respirator up to $18 \%$ in terms of $2 \mathrm{mg} / \mathrm{m}^{3} \mathrm{MAC}$ is recorded. It should be noted that non-use of respirators or their taking off for more than five minutes per working shift, in terms of constant dusting, results in the increase in under-mask concentration by almost three times.

3. Efficiency of miners' protection may be improved by intensification of the control of individual dust load on miners which will be evaluated taking into consideration real time of respirator use and changes in dust concentration within a working zone owing to the use of electronic means for monitoring developed on the basis of pressure sensors, power-supply units, units to control and process information, signal blocks, and units to record and store information.

\section{References.}

1. Vitrishchak, C. V., Savina, O. L., Klymenko, K. V., Haidash, I.A. and Kurchanova, V.S., 2012. Effect of working factors of coal mines upon the occupational health of miners. Ukrainian journal of clinical and laboratory medicine [online], 7(1), pp. 194-198. Available at: <http://nbuv.gov.ua/UJRN/Ujkl_2012_7_1_42> [Accessed 14 July 2017].

2. Cheberiachko, S., Yavors'ka, O., Radchuk, D. and Yavorskyi, A., 2018. Respiratory protection provided by negative pressure half mask filtering respirators in coal mines, Solid State Phenomena, 277, pp. 232-240. DOI:10.4028/www.scientific.net/SSP.277.232.

3. Kaptsov, V.A. and Chirkin, A. V., 2013. Prevention of occupational diseases while using gas respirators. $H y$ giene and sanitary, 3, pp. 42-45. DOI: 10.17686/sced_ rusnauka_2013-1109.

4. Kirillov, V. F., Buchnev, A.A. and Chirkin, A. V., 2013. On individual respiratory protective devices for workers (literature review). Occupatioanl medicine and industrial ecology, 4, pp. 25-31. DOI: 10.17686/sced_ rusnauka_2013-1033.

5. Bergman, M.S., Viscusi, D. J., Zhuang, Z. and Newcomb, W. E., 2013. Evaluation of Sampling Probes for Fit Testing N95 Filtering Facepiece Respirators. The Annals of Occupational Hygiene, 57(4), pp. 507-518. DOI: 10.1093/annhyg/mes091.

6. Holinko, V.I., Cheberiachko, S. I., Naumov, M. M. and Cheberiachko, Yu. I., 2014. Comparative studies of protective efficiency of filtering respirators under labo- ratory and industrial conditions. Naukovyi Visnyk Natsionalnoho Hirnychoho Universytetu, 1, pp. 139-144.

7. Levishko, K. V. and Kvitkovskyi, Yu. V., 2015. Methodology to calculate levels of production risks in terms of the profession of stopper. Collection of scientific papers of Kharkiv University of Air Forces, 2(43), pp. 123-128.

8. DSTU-П OHSAS 18001:2006. Systems to control occupational safety and health. Requirements [online]. Available at: $<$ http://metrology.com.ua/download/ isoiec-ohsas-i-dr/61-iso/519-dstu-p-ohsas-18001-2006> [Accessed 23 September 2017].

9. Kirillov, V.F. and Chirkin, A. V., 2015. Preventive measures against occupational diseases of miners in terms of dust effect. Coal, 3, pp. 50-52.

10. Andrushchenko, T.A., Basanets, A. V., Illiash, M.H. and Lubianova, I.P., 2011. Modern ways to prevent diseases of blood circulation system (arterial hypertension and ischemic heart disease) of miners of Ukrainian coal mines. Journal of the National Academy of Medical Sciences of Ukraine [online], 17(4), pp. 381-397. Available at: <http:// opb.org.ua/id/eprint/74> [Accessed 11 July 2017].

\section{Оцінка професійного ризику захворювання органів дихання працівників вугільних шахт}

\section{С. І. Чеберячко, А. В.Яворський, О. О.Яворська, В. В. Тихоненко}

Державний вищий навчальний заклад „Національний гірничий університет“, м. Дніпро, Україна, e-mail: elenayavorska80@gmail.com

Мета. Визначення рівня професійного ризику виникнення захворювання органів дихання на пневмоконіози у гірників при використанні фільтрувальних респіраторів.

Методика. Для оцінки професійних ризиків був використаний підхід, описаний у ДСТУ-П OHSAS 18001:2006 „Системи управління безпекою та гігієною праці. Вимоги“.

Результати. Встановлено, що область безпечного використання фільтрувальних півмасок в умовах вугільних шахт повинна бути обмежена 5 ГДК. Розрахунок рівня ризику при використанні методу "Risk score", показав, що при концентрації вугіль-

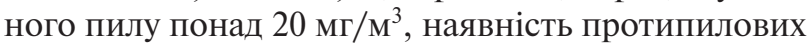
респіраторів дозволяє забезпечити лише помірний ступінь ризику виникнення професійних захворювань. При цьому фіксується перевищення підмаскової концентрації пилу в респіраторі до $18 \%$ при ГДК 2 мг $/ \mathrm{M}^{3}$. Відмічено, шо невикористання респіраторів або їх знімання на час більше ніж п'ять хвилин за робочу зміну при сталій запиленості призводить до збільшення підмаскової концентрації пилу майже утричі.

Наукова новизна. Полягає в науковому обгрунтуванні безпечної концентрації пилу, за якої можна забезпечити мінімальний ризик виникнення професійного захворювання на пневмоконіоз при використанні фільтрувального респіратору.

Практична значимість. Запропоновані заходи щодо зменшення рівня ризику виникнення профе- 
сійних захворювань на пневмоконіоз. Підвищення ефективності захисту гірників можливе за рахунок посилення контролю за індивідуальним пиловим навантаженням на гірників, що буде оцінюватись 3 урахуванням реального часу використання респіратора та зміни концентрації пилу в робочій зоні. Рекомендоване використання електронних засобів моніторингу, розроблених на базі датчику тиску, блоків живлення, управління та обробки інформації, сигналізації, запису та зберігання даних.

Ключові слова: вугільна шахта, пил, пневмоконіоз, величина ризику, питоме пиловиділення, очисний комбайн, засоби знепилювання

\section{Оценка профессионального риска заболевания органов дыхания работников угольных шахт}

\section{С. И. Чеберячко, А. В. Яворский, Е. А. Яворская, В. В. Тихоненко}

Государственное высшее учебное заведение „Национальный горный университет“, г. Днепр, Украина, e-mail: elenayavorska80@gmail.com

Цель. Определение уровня профессионального риска возникновения заболевания органов дыхания пневмокониозом у горняков при использовании фильтрующих респираторов.

Методика. Для оценки профессиональных рисков был использован подход, описанный в ГОСТ-П OHSAS 18001: 2006 „Системы управления безопасностью и гигиеной труда. Требования“".

Результаты. Установлено, что область безопасного использования фильтрующих полумасок в условиях угольных шахт, должна быть ограничена 5 ПДК. Расчет уровня риска при использовании ме- тода "Risk score", показал, что при концентрации угольной пыли более $20 \mathrm{мг} / \mathrm{M}^{3}$, наличие противопылевых респираторов позволяет обеспечить лишь умеренную степень риска возникновения профессиональных заболеваний. При этом фиксируется превышение массовой концентрации пыли в респираторе до $18 \%$ при ПДК 2 мг/ $\mathrm{M}^{3}$. Отмечено, что неиспользование респираторов или их снятие на время более пяти минут за рабочую смену при постоянной запыленности, приводит к увеличению подмасочной концентрации пыли почти в три раза.

Научная новизна. Заключается в научном обосновании безопасной концентрации пыли, при которой можно обеспечить минимальный риск возникновения профессионального заболевания пневмокониозом при использовании фильтрующего респиратора.

Практическая значимость. Предложены меры по уменьшению уровня риска возникновения профессиональных заболеваний пневмокониозом. Повышение эффективности защиты горняков возможно за счет усиления контроля за индивидуальными пылевыми нагрузками на горняков, которые будут оцениваться с учетом реального времени использования респиратора и изменения концентрации пыли в рабочей зоне. Рекомендовано использование электронных средств мониторинга, разработанных на базе датчика давления, блоков питания, управления и обработки информации, сигнализации, записи и хранения данных.

Ключевые слова: угольная шахта, пыль, пневмокониоз, величина риска, удельное пылевыделение, очистной комбайн, средства обеспыливания

Рекомендовано до публікації докт. техн. наук В. І. Голіньком. Дата надходження рукопису 18.09.17. 